\title{
Thromboxane-Associated Pulmonary Hypertension during Three Types of Gram- Positive Bacteremia in Piglets
}

\author{
RONALD L. GIBSON, WILLIAM E. TRUOG, AND GREGORY J. REDDING \\ Department of Pediatrics, Divisions of Neonatal and Respiratory Diseases, University of Washington School of \\ Medicine, Seattle, Washington 98195
}

\begin{abstract}
Thromboxane-associated pulmonary hypertension occurs in animals during intravenous infusion of group B streptococcus (GBS), a gram-positive neonatal pathogen. We postulated that other gram-positive neonatal pathogens, such as Streptococcus fecalis (ENT) and Staphylococcus epidermidis (S. epi) would also induce increased thromboxane synthesis and pulmonary hypertension when infused into piglets. We observed similar hemodynamic and gas exchange abnormalities during stepwise increases in the dose of GBS, Ent, and S. epi $(n=3,4$, and 4 piglets receiving each bacteria, respectively). Pulmonary vascular resistance increased significantly in the absence of acidosis or reduced arterial or mixed venous $\mathrm{pO}_{2}$ at a dose of $2.5 \times$ $10^{8} \mathrm{cfu} / \mathrm{kg} / \mathrm{h}$ for Ent and S. epi. In 14 additional piglets, pulmonary vascular resistance increased markedly after 60 min of intravenous infusion of $4 \pm 1 \times 10^{8} \mathrm{cfu} / \mathrm{kg} / \mathrm{h}$ for each organism $(p<0.05$, GBS: $11.7 \pm 1.8$ to $75.6 \pm 18.4$ $\mathrm{mm} \mathrm{Hg} / \mathrm{liter} / \mathrm{min}$, Ent: $12.7 \pm 1.7$ to $64.9 \pm 10.6 \mathrm{~mm} \mathrm{Hg} /$ liter/min, S. epi: $10.5 \pm 0.8$ to $56.9 \pm 6.0 \mathrm{~mm} \mathrm{Hg} / \mathrm{liter} /$ $\min$ ), and blood thromboxane B2 levels increased ( $p<$ 0.05 , GBS: $30 \pm 10$ to $1830 \pm 330 \mathrm{pg} / \mathrm{ml}$, Ent: $20 \pm 7$ to $1110 \pm 300 \mathrm{pg} / \mathrm{ml}$, S. epi: $31 \pm 9$ to $1260 \pm 350 \mathrm{pg} / \mathrm{ml})$. This dose of each bacteria caused a similar degree of mild arterial hypoxemia $(57-66 \mathrm{~mm} \mathrm{Hg}$ ). The thromboxane synthetase inhibitor, dazmegrel, completely reversed pulmonary hypertension, reduced TxB2 levels to near baseline values, and partially reversed arterial hypoxemia despite ongoing bacterial infusion. We conclude that thromboxaneassociated pulmonary hypertension occurs in piglets during infusion of different gram-positive neonatal pathogens. $(\mathrm{Pe}$ diatr Res 23: 553-556, 1988)
\end{abstract}

\section{Abbreviations}

cfu, colony forming units

C.O., cardiac output

DAZ, dazmegrel

Ent, Streptococcus fecalis (enterococcus)

GBS, group B streptococcus

$P_{\text {pa }}$, pulmonary artery pressure

PVR, pulmonary vascular resistance

$P_{w}$, pulmonary capillary wedge pressure

S. epi, Staphylococcus epidermidis

TxB2, thromboxane B2

TxA2, thromboxane A2

IV, intravenous

Received October 9, 1987; accepted January 20, 1988. Correspondence Ronald L. Gibson, Department of Pediatrics, RD-20, University of Washington, Seattle, WA 98195 .

Supported in part by $\mathrm{MCH} 000955$, the American Lung Association of Washington, and an American Lung Association Research Training Award.
$P_{\text {aw }}$, proximal airway pressure

$P_{\text {sa, }}$ systemic arterial pressure

GBS, a common gram-positive neonatal pathogen, causes acute pulmonary hypertension, arterial hypoxemia, and decreased cardiac output when infused into both adult and neonatal animals (1-3). In animals with GBS bacteremia and in some human newborns with GBS sepsis, pulmonary hypertension is associated with elevated blood levels of TxB2, the stable metabolite of the potent vasoconstrictor thromboxane $A_{2}(2,4,5)$. Inhibitors of thromboxane synthesis, such as DAZ (UK 38, 485), can prevent or reverse pulmonary hypertension in animals with GBS bacteremia $(4,6)$.

The fact that both gram-positive bacteria, e.g. GBS, and some gram-negative bacteria, e.g. E scherichia coli and Aeromonas hydrophilia $(7,8)$, can cause thromboxane-associated pulmonary hypertension suggests a lack of bacterial specificity for this pulmonary vascular response. Gram-positive neonatal pathogens other than GBS, such as Ent and S. epi, can contribute to respiratory failure and morbidity in human newborns $(9,10)$. However, there are no reports on the pulmonary hemodynamic effects of these other gram-positive bacteria.

We postulated that the intravenous infusion of gram-positive neonatal pathogens other than GBS into neonatal piglets might also cause elevation of blood thromboxane levels and pulmonary hypertension. Therefore, we also postulated that the administration of DAZ during ongoing infusion of bacteria other than GBS would reverse the pulmonary hypertension. Our hypothesis was tested by measuring pulmonary vascular responses and thromboxane levels in piglets before and during infusion of (1) GBS, (2) Ent, an enterococcal species containing the Lancefield group $\mathrm{D}$ antigen, and (3) S. epi, a nonstreptococcal species.

\section{METHODS}

Twenty-five piglets, $18 \pm 4$ days of age, and weighing $3.5 \pm$ $0.3 \mathrm{~kg}$ were anesthetized $(20 \mathrm{mg} / \mathrm{kg}$ pentobarbital IV), paralyzed $(0.3 \mathrm{mg} / \mathrm{kg}$ pancuronium bromide IV), heparinized (1000 IU IV), and mechanically ventilated via a metal tracheostomy with a large animal Harvard ventilator adjusted to deliver a tidal volume of $10 \pm 2 \mathrm{ml} / \mathrm{kg}$ at a rate to maintain $\mathrm{PaCO}_{2}$ at $40 \pm 5$ $\mathrm{mm} \mathrm{Hg}$ during baseline conditions. All animals were ventilated with room air throughout each experiment. A 5 Fr Swan-Ganz thermodilution catheter was positioned in a branch of the left pulmonary artery under fluoroscopy to measure $P_{p a}$ and $P_{w}$ and C.O. by thermodilution using an Edwards cardiac output computer, and to sample mixed venous blood. A polyethylene (PE 160) catheter was placed in the aorta via the left internal carotid 
artery to measure $\mathrm{P}_{\mathrm{sa}}$ and sample arterial blood for $\mathrm{pH}$, blood gas tensions, and arachidonic acid metabolite measurements. A polyethylene catheter (PE 90) was inserted into the left external jugular vein for infusion of bacteria. After instrumentation, anesthesia and muscle paralysis were maintained with pentobarbital ( $3 \mathrm{mg} / \mathrm{kg} \mathrm{IV} \mathrm{q} 1-2 \mathrm{~h})$ and pancuronium bromide $(0.3 \mathrm{mg} /$ $\mathrm{kg}$ IV q $1-2 \mathrm{~h}$ ), respectively. All piglets demonstrated $\mathrm{a}^{\mathrm{PaO}_{2}}$ of more than $80 \mathrm{~mm} \mathrm{Hg}$ and a pulmonary artery pressure less than $20 \mathrm{~mm} \mathrm{Hg}$ while breathing room air after instrumentation. Animals received sighs to $30 \mathrm{~cm} \mathrm{H}_{2} \mathrm{O}$ every 20 min to minimize spontaneous development of atelectasis. All vascular pressures were measured using Hewlett-Packard 1280 transducers and referenced to mid-chest; $P_{a w}$ was measured with a Statham P50 transducer at the tracheostomy port. Rectal temperature was maintained between $38.5 \pm 0.5^{\circ} \mathrm{C}$ with an overhead radiant heat source.

Group B $\beta$-hemolytic streptococcus (type III, $\mathrm{COH}$-1), Ent (CG 110), and S. epi (V.L. strain) were originally clinical isolates from neonates at Children's Hospital and Medical Center, Seattle, WA. Bacteria were inoculated into Todd-Hewitt broth and incubated at $36^{\circ} \mathrm{C}$ for $18 \mathrm{~h}$ before each experiment. The broth culture was centrifuged at $1000 \times g$ at $2^{\circ} \mathrm{C}$ for $15 \mathrm{~min}$, the bacterial pellet was resuspended in sterile isotonic saline, recentrifuged at $1000 \times g$ for $15 \mathrm{~min}$, and resuspended in sterile isotonic saline. The purity of each inoculum was assessed by colony morphology on blood agar. Bacterial concentration of the resuspensions was determined by measurement of optical density at $800 \mathrm{~nm}$ with comparison to previous plots of bacterial cfu on blood agar versus O.D. at $800 \mathrm{~nm}$ for each organism. The inoculum was then diluted with isotonic saline such that an infusion rate of $0.1 \mathrm{ml} / \mathrm{min}$ provided $5 \times 10^{8} \mathrm{cfu} / \mathrm{kg} / \mathrm{h}$. The diluted inoculum was inspected under light microscopy and showed no evidence of bacterial aggregation. Quantitative bacterial cultures were performed by serial dilution of arterial blood samples in sterile isotonic saline and subsequent plating onto blood agar.

In pilot experiments, a 1:50 dilution of Todd-Hewitt broth was infused via the central venous catheter at a rate of $0.1 \mathrm{ml} /$ min for $20 \mathrm{~min}$, and we observed no change in hemodynamic or gas exchange values in three piglets. This dilution of medium was selected as a generous estimate of possible contamination of the twice-washed bacterial pellet. In addition, undiluted supernatant from $\mathrm{S}$. epi and Ent cultures was filtered $(0.2-\mu$ pore size) and infused at a rate of $0.1 \mathrm{ml} / \mathrm{min}$ with no change in hemodynamic or gas exchange values.

The relationship between IV bacterial infusion dose and pulmonary vascular resistance was first determined for each organism. Hemodynamic indices including $\mathrm{P}_{\mathrm{pa}}, \mathrm{P}_{\mathrm{w}}, \mathrm{P}_{\mathrm{sa}}$, C.O., and blood gas tensions were measured before bacterial infusion and at $20 \mathrm{~min}$ after each stepwise increase in the bacterial infusion doses beginning with $5 \times 10^{7} \mathrm{cfu} / \mathrm{kg} / \mathrm{h}$, and increasing to $1 \times$ $10^{8} \mathrm{cfu} / \mathrm{kg} / \mathrm{h}, 2.5 \times 10^{8} \mathrm{cfu} / \mathrm{kg} / \mathrm{h}$, and finally $5 \times 10^{8} \mathrm{cfu} / \mathrm{kg} / \mathrm{h}$.

In each piglet, $\mathrm{P}_{\mathrm{pa}}, \mathrm{P}_{\mathrm{w}}, \mathrm{P}_{\mathrm{sa}}$, C.O., arterial and mixed venous blood gas tensions, proximal airway pressure, arterial blood samples for TxB2 measurement, and quantitative arterial blood cultures were subsequently obtained under three conditions: 1) before bacterial infusion (PRE), 2) $60 \mathrm{~min}$ after the onset of the bacterial infusion via the central venous catheter at a dose of 4 $\pm 1 \times 10^{8} \mathrm{cfu} / \mathrm{kg} / \mathrm{h}(60 \mathrm{~min})$, and 3) $90 \mathrm{~min}$ after the onset of the bacterial infusion and $30 \mathrm{~min}$ after a 5 -minute IV infusion of $8 \mathrm{mg} / \mathrm{kg}$ of DAZ, a thromboxane synthetase inhibitor. The powder from of DAZ (UK 38, 435 kindly provided by $R$. Urguilla, Pfizer Laboratories, Groton, CT) was dissolved in 1.5 $\mathrm{ml}$ of $0.1 \mathrm{~N} \mathrm{NaOH}$ and $0.9 \%$ saline was added to a volume of $7.5 \mathrm{ml}$. For this part of the study, five additional piglets received Ent, five additional piglets received $\mathrm{S}$. epi, and four additional piglets received GBS.

Under each experimental condition (PRE, $60 \mathrm{~min}$, and DAZ), $2 \mathrm{ml}$ of arterial blood were obtained for measurement of TxB2. The blood drawn into a cyclooxygenase inhibitor solution of 0.6 $\mathrm{mg}$ indomethacin and $2 \mathrm{mg}$ EDTA/ml of blood. The inhibitor solution and the inhibitor solution-blood mixture were kept in an ice-water bath until centrifugation at $25,000 \times \mathrm{g}$ for $20 \mathrm{~min}$ at $0^{\circ} \mathrm{C}$. The decanted supernatant was promptly frozen at $-70^{\circ}$ $\mathrm{C}$ until analysis by radioimmunoassay in the laboratory of Dr. William Henderson, University of Washington, as previously reported (4).

Cardiac output was measured in triplicate during each experimental condition, and if there was a more than $10 \%$ variation in those values a fourth measurement was included for determining the average. PVR was calculated ( $\mathrm{PVR}=\mathrm{P}_{\mathrm{pa}}-\mathrm{P}_{\mathrm{w}} /$ C.O. $)$. The arterial blood samples for $\mathrm{T} \times \mathrm{B} 2$ measurement were analyzed in duplicate by radioimmunoassay; the average of the two assays was used to determine means for the different experimental groups. Paired $t$ tests were used to ascertain statistical significance between prebacterial infusion values and the two subsequent experimental conditions for each type of bacteria. A $p$ value of less than 0.05 was considered significant.

\section{RESULTS}

The relationship between bacterial infusion dose and pulmonary vascular resistance for each organism is shown in Figure 1. These experiments were performed to study the effects of increments in the bacterial infusion on pulmonary hemodynamics, C.O., and gas exchange. In addition these data were used to determine a common infusion dose for the three organisms that would cause sustained pulmonary hypertension in the absence of marked hypoxemia or hypotension. There was a similar doseresponse relationship for each organism with a significant elevation in PVR at doses of $2.5 \times 10^{8} \mathrm{cfu} / \mathrm{kg} / \mathrm{h}$ for Ent and S. epi and continued elevation in PVR at a dose of $5 \times 10^{8} \mathrm{cfu} / \mathrm{kg} / \mathrm{h}$ for all types of bacteria. At a dose of $2.5 \times 10^{8} \mathrm{cfu} / \mathrm{kg} / \mathrm{h}, \mathrm{PVR}$ increased from preinfusion values predominantly due to a doubling of $\mathrm{P}_{\mathrm{pa}}$ (GBS: $14.3 \pm 0.9$ to $30.0 \pm 7.0 \mathrm{~mm} \mathrm{Hg}$, Ent: $15.2 \pm$
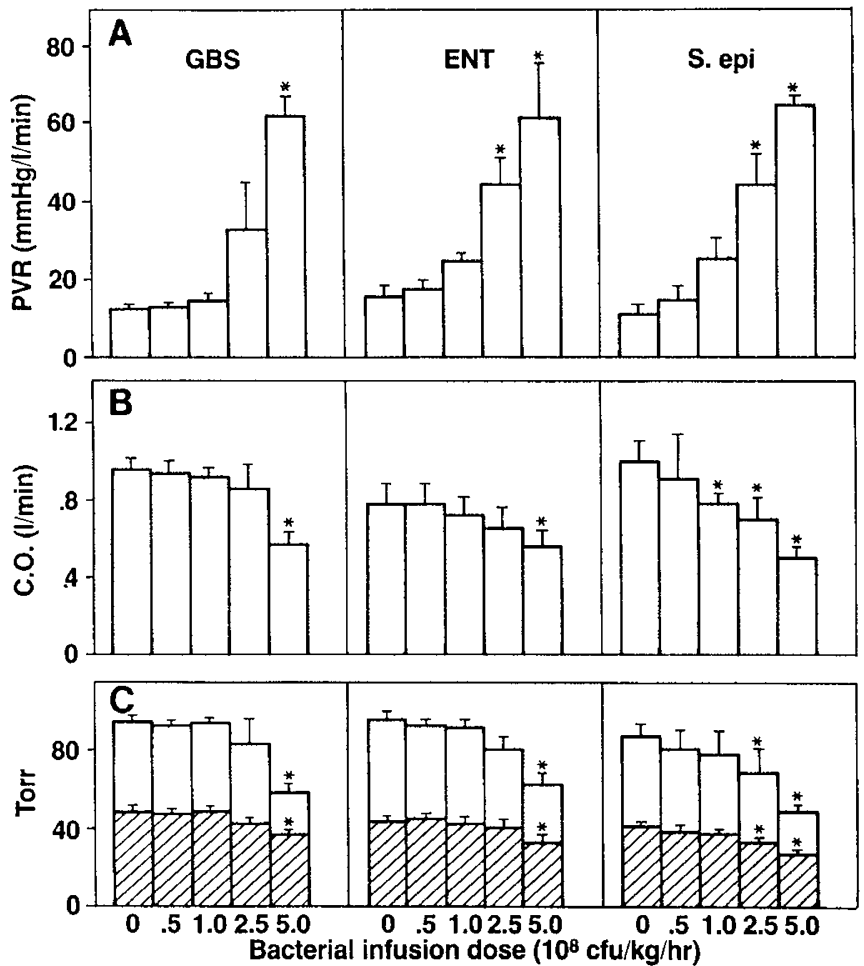

Fig. 1. Cardiopulmonary responses to increasing doses of three grampositive bacteria. $A$, PVR versus bacterial infusion dose; $B$, C.O. versus bacterial infusion dose; $C$, blood gas tensions versus bacterial infusion dose. Open bars represent $\mathrm{PaO}_{2}$ and cross-hatched bars represent $\mathrm{PvO}_{2}$. Values are expressed as mean $\pm \mathrm{SEM},{ }^{*} p<0.05$ compared to preinfusion value. 
1.7 to $31.0 \pm 1.4 \mathrm{~mm} \mathrm{Hg}$, and S. epi: $14.3 \pm 2.3$ to $35.2 \pm 4.0$ $\mathrm{mm} \mathrm{Hg}$ ), as well as a $15-30 \%$ decrease in C.O. (Fig. 1). The further increase in PVR at doses of $5 \times 10^{8} \mathrm{cfu} / \mathrm{kg} / \mathrm{h}$ was due to both an increase in $\mathrm{P}_{\mathrm{pa}}$ (GBS: $39.7 \pm 2.2 \mathrm{~mm} \mathrm{Hg}$, Ent: $35.4 \pm$ $1.1 \mathrm{~mm} \mathrm{Hg}$, and S. epi: $40.2 \pm 2.5 \mathrm{~mm} \mathrm{Hg}$ ), and a $30-50 \%$ decrease in C.O. from preinfusion values.

The increase in PVR at a dose of $2.5 \times 10^{8} \mathrm{cfu} / \mathrm{kg} / \mathrm{h}$ of Ent occurred in the absence of acidosis, arterial hyoxemia, or significant reduction in mixed venous oxygen tension (Fig. 1); the increase in PVR at a dose of $2.5 \times 10^{8} \mathrm{cfu} / \mathrm{kg} / \mathrm{h}$ of S. epi was associated with statistically significant decreases in both arterial and mixed venous $\mathrm{pO}_{2}$, but values that remained within normal limits for piglets (Fig. 1). Due to the differences in the bacterial dose producing pulmonary hypertension for different types of bacteria, an infusion of $4 \pm 1 \times 10^{8} \mathrm{cfu} / \mathrm{kg} / \mathrm{h}$ of each organism was selected for the remaining experiments to ensure significant elevation of $\mathrm{P}_{\mathrm{pa}}$ in all animals during the entire 1-h infusion.

The pulmonary hemodynamic response to a 1-h infusion of 4 $\pm 1 \times 10^{8} \mathrm{cfu} / \mathrm{kg} / \mathrm{h}$ and the effect of the thromboxane synthetase inhibitor, DAZ, on pulmonary vascular resistance during bacterial infusion are shown in Table 1. For each gram-positive organism there was a similar and sustained elevation in PVR during the 1-h infusion, with marked increases in PVR above the preinfusion values. Thirty min after the administration of DAZ despite ongoing infusion of bacteria, PVR returned to preinfusion values for all three types of bacteria. All three bacteria caused a similar and significant increase in $\mathrm{P}_{\mathrm{pa}}$ during the infusion, and there was a significant increase in $P_{w}$ during both GBS and Ent infusion (Table 1). Elevated pulmonary artery and pulmonary capillary wedge pressures were reduced 30 min after administration of DAZ despite ongoing infusion of all three types of bacteria. C.O. was decreased to approximately $60 \%$ of baseline values $1 \mathrm{~h}$ after the onset of each infusion, with partial return to preinfusion values after infusion of DAZ (Table 1). This decrease in C.O. was associated with a $10-20 \%$ increase in heart rate, but no reduction in systemic arterial pressure. Although there were small but statistically significant reductions in $\mathrm{pH}$ and increases in $\mathrm{PaCO}_{2}$ values after $60 \mathrm{~min}$ of bacterial infusion for all three organisms, no abnormal values for $\mathrm{pH}$ or $\mathrm{PaCO}_{2}$ in piglets occurred (Table 2). In addition, after $60 \mathrm{~min}$ of infusion of each type of bacteria, there was a significant reduction in both $\mathrm{PaO}_{2}$ and $\mathrm{PvO}_{2}$. After administration of $\mathrm{DAZ}$ values of both $\mathrm{PaO}_{2}$ and $\mathrm{PvO}_{2}$ partially returned to prebacterial infusion values (Table 2).

TxB2 levels are presented in Table 3 . Arterial TxB2 levels were

Table 1. Similar hemodynamic responses to three gram-positive pathogens and $D A Z$ in piglets (mean $\pm S E M)^{*}$

\begin{tabular}{|c|c|c|c|c|}
\hline & $\begin{array}{c}\mathrm{P}_{\mathrm{pa}} \\
(\mathrm{mm} \mathrm{Hg})\end{array}$ & $\begin{array}{c}\mathrm{P}_{\mathrm{w}} \\
(\mathrm{mm} \mathrm{Hg})\end{array}$ & $\begin{array}{c}\text { C.O. } \\
\text { (liter/min) }\end{array}$ & $\begin{array}{c}\text { PVR } \\
\text { (mm Hg/ } \\
\text { liter/min) }\end{array}$ \\
\hline \multicolumn{5}{|c|}{ GBS $(n=4)$} \\
\hline PRE & $13.5 \pm 1.0$ & $2.6 \pm 0.5$ & $0.95 \pm 0.06$ & $11.7 \pm 1.8$ \\
\hline $60^{\prime}$ & $44.0 \pm 1.9 \dagger$ & $6.3 \pm 0.6 \dagger$ & $0.56 \pm 0.11 \dagger$ & $75.6 \pm 18.4 \dagger$ \\
\hline DAZ & $14.0 \pm 1.6$ & $2.8 \pm 0.5$ & $0.75 \pm 0.05 \dagger$ & $14.3 \pm 2.5$ \\
\hline \multicolumn{5}{|c|}{ Ent $(n=5)$} \\
\hline PRE & $14.3 \pm 1.2$ & $2.5 \pm 0.2$ & $0.96 \pm 0.11$ & $12.7 \pm 1.7$ \\
\hline $60^{\prime}$ & $39.6 \pm 2.3 \dagger$ & $5.2 \pm 0.4 \dagger$ & $0.57 \pm 0.07 \dagger$ & $64.9 \pm 10.6 \dagger$ \\
\hline DAZ & $13.6 \pm 0.8$ & $3.2 \pm 0.3$ & $0.83 \pm 0.06 \dagger$ & $12.8 \pm 1.4$ \\
\hline \multicolumn{5}{|c|}{ S. epi $(n=5)$} \\
\hline PRE & $13.4 \pm 1.0$ & $3.6 \pm 0.6$ & $0.99 \pm 0.11$ & $10.5 \pm 0.8$ \\
\hline $60^{\prime}$ & $37.3 \pm 2.2 \dagger$ & $4.6 \pm 0.3$ & $0.59 \pm 0.08 \dagger$ & $56.9 \pm 6.0 \dagger$ \\
\hline DAZ & $12.4 \pm 0.8$ & $2.7 \pm 0.5$ & $0.79 \pm 0.05$ & $12.7 \pm 0.9$ \\
\hline
\end{tabular}

* PRE, before bacterial infusion; $60^{\prime}, 60$ min into bacterial infusion; $\mathrm{DAZ}, 30 \mathrm{~min}$ after administration of DAZ with ongoing bacterial infusion.

$\dagger p<0.05$ compared to baseline (PRE). all less than $100 \mathrm{pg} / \mathrm{ml}$ before bacterial infusion, which represents the limit of TxB2 detection by radioimmunoassay. Arterial TxB2 levels increased significantly $60 \mathrm{~min}$ after the onset of infusion of each gram-positive organism $(p<0.05)$, and returned to near preinfusion values in all piglets $30 \mathrm{~min}$ after administration of DAZ.

Quantitative arterial blood cultures were performed to ensure sterility before experimental bacterial infusion, to determine the degree of bacteremia during these relatively low-dose infusions $\left(4 \pm 1 \times 10^{8} \mathrm{cfu} / \mathrm{kg} / \mathrm{h}\right)$, and to ensure there were no antimicrobial effects of DAZ. No piglets had evidence of bacteremia before experimental bacterial infusion. One $h$ after the onset of the same bacterial infusion dose, we observed similar arterial blood colony counts for S. epi $\left(6.6 \pm 1.5 \times 10^{4} \mathrm{cfu} / \mathrm{ml}\right)$ and Ent $(12.1$ $\pm 6.2 \times 10^{4} \mathrm{cfu} / \mathrm{ml}$ ), but 5 - to 10 -fold lower blood colony counts for GBS $\left(1.3 \pm 0.4 \times 10^{4} \mathrm{cfu} / \mathrm{ml}\right)$. Due to variability of bacterial concentration in blood among different piglets receiving the same bacterial infusion dose, the GBS culture results were only significantly different from S. epi values. Blood colony counts of all three organisms did not change significantly after administration of DAZ (GBS: $2.0 \pm 0.5 \times 10^{4} \mathrm{cfu} / \mathrm{ml}$, Ent: $6.7 \pm 3.0 \times 10^{4} \mathrm{cfu} /$ $\mathrm{ml}$, and S. epi: $\left.5.9 \pm 1.9 \times 10^{4} \mathrm{cfu} / \mathrm{ml}\right)$.

\section{DISCUSSION}

Pulmonary hypertension and concomitant elevations of arterial blood TxB2 levels occurred in neonatal piglets during IV infusion of GBS, Ent, and S. epi. The increase in PVR and TxB2 levels were reversed after the administration of a thromboxane synthetase inhibitor, DAZ, providing further evidence for thromboxane-associated pulmonary hypertension during several forms

Table 2. Similar blood gas changes in response to three grampositive pathogens and $D A Z$ in piglets (mean $\pm S E M$ )*

\begin{tabular}{lclll}
\hline & $\mathrm{pH}$ & $\begin{array}{c}\mathrm{PaCO}_{2} \\
(\mathrm{~mm} \mathrm{Hg})\end{array}$ & $\begin{array}{c}\mathrm{PaO}_{2} \\
(\mathrm{~mm} \mathrm{Hg})\end{array}$ & $\begin{array}{c}\mathrm{PvO}_{2} \\
(\mathrm{~mm} \mathrm{Hg})\end{array}$ \\
\hline $\mathrm{GBS}(n=4)$ & & & & \\
$\mathrm{PRE}$ & $7.40 \pm 0.03$ & $41 \pm 2$ & $93 \pm 3$ & $48 \pm 1$ \\
$60^{\prime}$ & $7.34 \pm 0.02$ & $40 \pm 3$ & $59 \pm 4 \dagger$ & $33 \pm 7$ \\
$\mathrm{DAZ}$ & $7.37 \pm 0.01$ & $38 \pm 2$ & $76 \pm 9$ & $44 \pm 2$ \\
& & & & \\
Ent $(n=5)$ & & & & \\
PRE & $7.44 \pm 0.02$ & $38 \pm 1$ & $94 \pm 2$ & $42 \pm 1$ \\
$60^{\prime}$ & $7.36 \pm 0.03 \dagger$ & $44 \pm 2 \dagger$ & $57 \pm 2 \dagger$ & $28 \pm 1 \dagger$ \\
DAZ & $7.39 \pm 0.02$ & $41 \pm 2$ & $69 \pm 5 \dagger$ & $36 \pm 3$ \\
& & & & \\
S. epi $(n=5)$ & & & & \\
PRE & $7.43 \pm 0.02$ & $37 \pm 1$ & $95 \pm 3$ & $44 \pm 2$ \\
$60^{\prime}$ & $7.36 \pm 0.02 \dagger$ & $42 \pm 2 \dagger$ & $66 \pm 8 \dagger$ & $31 \pm 2 \dagger$ \\
DAZ & $7.41 \pm 0.02$ & $38 \pm 2$ & $81 \pm 3 \dagger$ & $39 \pm 1 \dagger$ \\
\hline
\end{tabular}

*PRE, before bacterial infusion; $60^{\prime}, 60 \mathrm{~min}$ into the bacterial infusion; DAZ, 30 min after administration of DAZ with ongoing bacterial infusion.

$\dagger p<0.05$ compared to PRE value.

Table 3. TXB2 levels increase during infusion of three grampositive bacteria in piglets (mean \pm SEM)*

\begin{tabular}{lccc}
\hline & $\begin{array}{c}\text { GBS } \\
(n=4)\end{array}$ & $\begin{array}{c}\text { Ent } \\
(n=5)\end{array}$ & $\begin{array}{c}\text { S. epi } \\
(n=5)\end{array}$ \\
\hline $\mathrm{PRE}(\mathrm{pg} / \mathrm{ml})$ & $30 \pm 10$ & $20 \pm 7$ & $31 \pm 9$ \\
$60^{\prime}(\mathrm{pg} / \mathrm{ml})$ & $1830 \pm 330 \dagger$ & $1110 \pm 300 \dagger$ & $1260 \pm 350 \dagger$ \\
$\mathrm{DAZ}(\mathrm{pg} / \mathrm{ml})$ & $310 \pm 95$ & $110 \pm 20 \dagger$ & $160 \pm 50$ \\
\hline
\end{tabular}

* PRE, before bacterial infusion; $60^{\prime}, 60$ min after the onset of the bacterial infusion; and DAZ, $30 \mathrm{~min}$ after the administration of dazmegrel with ongoing bacterial infusion.

$\dagger p<0.05$ compared to PRE values. 
of gram-positive bacteremia in piglets. Pulmonary hypertension in response to GBS infusion has previously been reported in piglets (1-4), but this study is the first to demonstrate similar degrees of pulmonary hypertension, elevated TxB2 levels, arterial hypoxemia, and reduction in cardiac output during Ent and $\mathrm{S}$. epi bacteremia in neonatal animals. Previous reports of hemodynamic changes in piglets due to GBS may be relevant to but not specific for GBS sepsis in human newborns.

The $P_{w}$ was elevated during GBS and Ent infusion, and returned to normal values after administration of dazmegrel. Simultaneous $P_{w}$ and left atrial pressures have not been measured during bacterial infusion in piglets, but there are previous independent observations of normal left atrial pressures and elevated $\mathrm{P}_{\mathrm{w}}$ during GBS infusion in piglets $(1,3,11,12)$. There is indirect evidence that thromboxane can cause pulmonary venoconstriction in sheep (13), which could explain an increase in $P_{w}$ with no change in left atrial pressure during bacterial infusion.

A component of the increase in PVR observed $1 \mathrm{~h}$ into bacterial infusion may also be secondary to hypoxic pulmonary vasoconstriction, as $\mathrm{PaO}_{2}$ fell from approximately 95 to 60 torr and $\mathrm{PvO}_{2}$ decreased from approximately 45 to 30 torr (Table 1). However, for all organisms we observed a bacterial dose-dependent increase in PVR, and with Ent and S. epi a significant increase in PVR occurred before developing significant reductions in arterial or mixed venous $\mathrm{pO}_{2}$ (Fig. 1). Furthermore, previous observations in our laboratory demonstrate a mean $\mathrm{P}_{\mathrm{pa}}$ of approximately $20-25 \mathrm{~mm} \mathrm{Hg}$ for piglets with a $\mathrm{PaO}_{2}$ of 60 torr, which would not explain the observed increases in mean $P_{p a}$ to $37-44 \mathrm{~mm} \mathrm{Hg}$ during our experiments (14).

Why thromboxane-associated pulmonary hypertension occurs in several animal species receiving IV gram-positive or gramnegative bacteria is uncertain. Some possibilities include 1) different components specific for each organism are capable of inducing pulmonary hypertension, 2) a bacterial component common to all organisms can induce pulmonary hypertension, or 3) a nonspecific circulating particulate/embolic effect is responsible for the physiological changes observed during bacterial infusion in piglets. There are data to support the first contention based on the different structures of $E$. coli endotoxin compared to two identified GBS polysaccharide "toxins," all of which produce pulmonary hypertension during IV infusion $(15,16)$. Two groups of investigators have identified two different GBS polysaccharide "toxins;" one is derived from the intact organism and apparently related to the GBS type and group specific polysaccharides (15), whereas the other is an unrelated mannan polysaccharide derived from GBS culture supernatant (16). No previous studies have described a common bacterial component that can induce pulmonary hypertension. In the piglet model used by several groups of investigators, a nonspecific particulate effect has not been excluded. A nonspecific embolic effect is less likely to explain our results due to the lack of bacterial aggregates in the inoculum. Furthermore, the lack of histological evidence for lung injury or pulmonary emboli by light microscopy in lung sections from related experiments in our laboratory (6), and the rapid reversal of pulmonary hypertension with administration of DAZ suggests a nonspecific particulate or embolic phenomenon is not responsible for pulmonary hypertension during grampositive bacteremia in piglets.

It is uncertain if the degree of bacteremia that produces pulmonary hypertension in piglets $\left(10^{4}-10^{5} \mathrm{cfu} / \mathrm{ml}\right)$ is relevant to human newborns with sepsis due to GBS, Ent, or S. epi. There are no reports on quantitative blood cultures from septic human newborns with GBS, Ent, or S. Epi; other pediatric pathogens including Hemophilus influenzae, Streptococcus pneumonia, and $E$. coli have been isolated in densities of more than $10^{3} \mathrm{cfu} / \mathrm{ml}$ from patients with sepsis of meningitis (17). The reason for a similar degree of pulmonary hypertension at a lower arterial blood colony density for GBS compared to Ent and S. epi is unclear. This finding suggests GBS may be a more potent stimulus for TxB2 synthesis and pulmonary hypertension. Alternatively, piglets may clear GBS more rapidly than Ent or S. epi but stimulate thromboxane-associated pulmonary vasoconstriction equally.

Our observations have potentially important clinical implications. Hammerman et al. (5) have reported elevated thromboxane levels in human infants with GBS sepsis and persistent pulmonary hypertension of the newborn, suggesting a pathogenic role for thromboxane in some of these cases. Therefore, it is possible that blood thromboxane levels may be elevated in human newborns with other forms of bacteremia. The clinical role of thromboxane synthetase inhibitors should be pursued as an adjunctive treatment for human newborns with hypoxemia, bacteremia, and pulmonary hypertension. Our results suggest there may be a common component in gram-positive organisms capable of inducing pulmonary hypertension. Identifying such a common component of gram-positive bacteria may offer new strategies for developing monoclonal antibody therapy to treat sepsis and pulmonary hypertension in newborns.

Acknowledgments. The authors thank Dr. Craig E. Rubens, Department of Pediatrics, University of Washington for providing the clinical isolates of bacteria tested, and for his advice. We thank Dr. William Henderson, Department of Medicine, University of Washington for the measurement of TxB2 levels. The authors appreciated the advice and assistance from Lorna Rabe, Elizabeth Lien, and Viki Hughes in the microbiological research lab in the Department of Obstetrics and Gynecology, University of Washington. We also thank Jo Ann Jarrett for secretarial assistance.

\section{REFERENCES}

1. Rojas J, Green RS, Hellerqvist CG, Olegard R, Brigham KL, Stahlman MT 1981 Studies on group B beta-hemolytic streptococcus. II. Effects on pulmonary hemodynamics and vascular permeability in unanesthetized sheep. Pediatr Res 15:899-904

2. Runkle B, Goldberg RN, Streitfeld MM, Clark MR, Buron E, Setzer ES, Bancalari E 1984 Cardiovascular changes in group B streptococcal sepsis in the piglet: response to indomethacin and the relationship to prostacyclin and thromboxane A2. Pediatr Res 18:874-878

3. Sorensen GK, Redding GJ, Truog WE 1985 Mechanisms of pulmonary gas exchange abnormalities during experimental group B streptococcal infusion. Pediatr Res 19:922-926

4. Truog WE, Sorensen GK, Standaert TA, Redding GJ 1986 Effects of the thromboxane synthetase inhibitor, dazmegrel (UK 38,485), on pulmonary gas exchange and hemodynamics in neonatal sepsis. Pediatr Res 20:481-486

5. Hammerman C, Lass N, Strates E, Komar K, Bui KC 1987 Prostanoids in neonates with persistent pulmonary hypertension. J. Pediatr 1 10:470-472

6. Truog WE, Gibson RL, Juul SE, Henderson WR, Redding GJ 1988 Neonatal group B streptococcal sepsis: effects of late treatment with dazmegrel. Pediatr Res 23:352-356

7. Hales CA, Sonne L, Peterson M, Miller M, Watkins WD 1981 Role of thromboxane and prostacyclin in pulmonary vasomotor changes after endotoxin in dogs. J Clin Invest 68:497-505

8. Slotman GJ, Quinn JV, Burchard KW, Gann DS 1985 Thromboxane, prostacyclin, and the hemodynamic effects of graded bacteremic shock. Circ Shock 16:395-404

9. Freedman RM, Ingram DL, Gross I, Ehrenkranz RA, Warshaw JB, Baltimore RS 1981 A half century of neonatal sepsis at Yale. Am J Dis Child 135:140144

10. Noel GJ, Edelson PJ 1984 Staphylococcus epidermidis bacteremia in neonates: further observations and the occurrence of focal infection. Pediatrics 74:832837

11. Suguihara C, Goldberg RN, Hehre D, Bancalari A, Bancalari E 1987 Effect of cyclooxygenase and lipoxygenase products on pulmonary function in group B streptococcal sepsis. Pediatr Res 22:478-482

12. Meadow WL, Meus PJ 1984 Hemodynamic consequences of tolazoline in neonatal group B streptococcal bacteremia: an animal model. Pediatr Res 18:960-965

13. Noonan TC, Malik AB 1986 Pulmonary vascular response to leukotriene D4 in unanesthetized sheep: role of thromboxane. J Appl Physiol 60:765-769

14. Redding GJ, Standaert TA, Truog WE 1986 Pulmonary vascular reactivity and gas exchange in response to global and regional hypoxia in newborn piglets. In: Tumbleson ME (ed) Swine in Biomedical Research, Vol 2. Plenum Press, New York, pp 1187-1194

15. Hemming VG, O'Brien WF, Fischer GW, Golden SM, Nobel SF 1984 Studies of short-term pulmonary and peripheral vascular responses induced in oophorectomized sheep by the infusion of a group B streptococcal extract. Pediatr Res 18:266-269

16. Hellerqvist CG, Sundell H, Gettins P 1987 Molecular basis for group B betahemolytic streptococcal disease. Proc Natl Acad Sci USA 84:51-55

17. Dietzman DE, Fischer GW, Schoenknecht FD 1974 Neonatal Escheridia coli septicemia-bacterial counts in blood. J Pediatr 85:128-130 